\title{
PERBANDINGAN DOSIS PIRIDOSTIGMIN, PERFORMA FUNGSIONAL, DAN DERAJAT KLINIS PASIEN MIASTENIA GRAVIS SEBELUM DAN SETELAH TIMEKTOMI
}

\author{
COMPARISON BETWEEN PYRIDOSTIGMINE DOSE, FUNCTIONAL \\ PERFORMANCE, AND CLINICAL SEVERITY IN MYASTHENIA GRAVIS \\ PATIENTS BEFORE AND AFTER THYMECTOMY
}

Christianty Sugiarto, * Sobaryati, * Henny Anggraini Sadeli, * Tri Wahyu Murni **

\section{ABSTRACT}

Introduction: Myasthenia gravis (MG) is highly associated with thymic abnormalities. Most cases, show decreasing dosage of drugs and improving of clinical symptoms after thymectomy. However, in Indonesia, there are only limited number of studies have evaluated it.

Aim: To evaluate and compare clinical condition of MG patients in Hasan Sadikin Hospital, Bandung before and after thymectomy.

Methods: A retrospective cohort and descriptive analytic study on adult $M G$ patients who had gone through thymectomy in Hasan Sadikin Hospital, Bandung from January 2014 to December 2016. Daily Pyridostigmine dosage comparison, functional performance using Myasthenia Gravis-Activities of Daily Living (MG-ADL) score, and clinical severity using Myasthenia Gravis Foundation of America (MGFA) classification before and six months after thymectomy were assessed.

Results: There are 27 subjects, female:male 2.8:1, with a mean age of $36.44 \pm 14.46$ years. Average daily Pyridostigmine dosage needed pre- and six months post-thymectomy were $240(180-540) \mathrm{mg}$ and $180(0-480) \mathrm{mg}$ respectively. The median of MG-ADL scores pre- and six months post-thymectomy were 10 (4-21) and 3(0-18) respectively. The median of MGFA classification pre-and six months post-thymectomy were grade IVa (IIa-V) and IIb (normal-V) respectively.

Discussion: There were significant decrease in daily Pyridostigmine dosage, improvements in functional performance, and improvements in clinical severity six months after thymectomy in $M G$ patients.

Keywords: $M G-A D L, M G F A$ classification, pyridostigmine, thymectomy

\section{ABSTRAK}

Pendahuluan: Penyakit miastenia gravis (MG) sering berhubungan dengan kelainan kelenjar timus. Pada kebanyakan kasus, timektomi dapat menurunkan kebutuhan dosis obat dan memperbaiki gejala klinis pasien MG. Di Indonesia penelitian mengenai hal ini masih sangat terbatas.

Tujuan: Mengetahui perbandingan kondisi klinis pasien MG antara sebelum dan setelah dilakukan timektomi di RSUP Dr. Hasan Sadikin, Bandung.

Metode: Penelitian kohort retrospektif, deskriptif analitik pada pasien MG dewasa yang telah dilakukan timektomi di RSUP Dr. Hasan Sadikin, Bandung, antara Januari 2014-Desember 2016. Dilakukan perbandingan dosis Piridostigmin per hari serta penilaian performa fungsional dengan skor Myasthenia Gravis-Activities of Daily Living (MG-ADL) dan derajat klinis berdasarkan klasifikasi Myasthenia Gravis Foundation of America (MGFA) antara sebelum dan 6 bulan setelah timektomi.

Hasil: Diperoleh 27 subjek, perempuan:laki-laki 2,8:1, rerata usia 36,4 $\pm 14,5$ tahun. Rerata dosis Piridostigmin per hari sebelum timektomi 240 (rentang 180-540)mg dan 6 bulan setelah timektomi 180 (0-480)mg. Median skor MG-ADL sebelum timektomi adalah 10 (4-21) dan 6 bulan setelah timektomi 3 (0-18). Median klasifikasi MGFA sebelum timektomi adalah IVa (rentang IIa-V) sedangkan 6 bulan setelah timektomi adalah IIb (rentang normal-V).

Diskusi: Terdapat penurunan dosis Piridostigmin, serta perbaikan performa fungsional dan derajat klinis yang bermakna antara sebelum dan 6 bulan setelah timektomi pada pasien MG.

Kata kunci: Klasifikasi MGFA, MG-ADL, piridostigmin, timektomi

*Departemen Neurologi FK Universitas Padjajaran/RSUP Dr. Hasan Sadikin, Bandung; **Departemen Bedah Toraks dan Kardiovaskular FK Universitas Padjajaran/RSUP Dr. Hasan Sadikin, Bandung. Korespondensi: christianty.sugiarto@gmail.com.

\section{PENDAHULUAN}

Miastenia gravis (MG) merupakan suatu penyakit yang menyebabkan kegagalan transmisi otot akibat proses auto antibodi terhadap reseptor nikotinik pada taut saraf-otot (neuromuscular junction/NMJ). Penyakit ini ditandai dengan kelemahan otot volunter yang berfluktuasi pada otot mata, otot batang tubuh, otot ekstremitas, otot bulbar, maupun otot pernapasan 
yang dapat menyebabkan gagal napas. Kelemahan otot tersebut secara langsung mengganggu aktivitas keseharian dan kemampuan bekerja, sehingga pada akhirnya menurunkan performa fungsional penderitanya. ${ }^{1-2}$

Penyakit MG dapat terjadi pada semua usia dengan rasio perempuan dibandingkan laki-laki sebesar 3:2. Prevalensinya adalah $0,5-20,4$ per 100.000 penduduk dengan insidens 0,3 kasus baru per 100.000 penduduk. ${ }^{1,3-9}$ Belum ada angka yang pasti di Indonesia, namun di Instalasi Rawat Jalan (IRJ) RSUP Dr. Hasan Sadikin Bandung tercatat 280 pasien MG pada tahun 2014-2016, dengan 115 pasien yang dirawat karena perburukan klinis dan 12 pasien meninggal dalam perawatan.

Sebanyak 75\% pasien MG memiliki kelainan kelenjar timus, $10-15 \%$ diantaranya timoma dan $70 \%$ merupakan hiperplasia folikular. ${ }^{10}$ Hampir 50\% pasien dengan kelainan kelenjar timus berkembang menjadi MG. ${ }^{11-12}$ Pada sebagian besar pasien, timektomi dapat memperbaiki gejala klinis dan menurunkan kebutuhan dosis Piridostigmin secara signifikan, bahkan hingga terjadi remisi. Risiko tindakan operasi sangat kecil dan akan menurunkan angka morbiditas dan mortalitas pasien MG. Oleh karena itu, timektomi menjadi salah satu terapi pilihan pada pasien MG dan menjadi faktor prognostik yang menguntungkan. ${ }^{1-3,10,13-15}$

Derajat klinis MG dibagi berdasarkan klasifikasi Myasthenia Gravis Foundation of America (MGFA) yang terdiri dari derajat I hingga $\mathrm{V}$ sesuai dengan tingkat keparahan klinis. Derajat I merupakan derajat yang paling ringan, yaitu MG okular. Derajat II, III, IV merupakan MG generalisata dengan berbagai tingkat keparahan, yaitu ringan, sedang, dan berat. Derajat $\mathrm{V}$ merupakan kondisi paling berat hingga harus diintubasi, dengan maupun tanpa ventilator mekanik (Tabel 1). ${ }^{16}$

Adapun penilaian kemampuan aktivitas keseharian dan performa fungsional pada pasien MG dapat diukur menggunakan kuesioner Myasthenia Gravis-Activities of Daily Living (MG-ADL). Kuesioner ini terdiri dari 8 hal (Tabel 2), sudah divalidasi serta memiliki sensitivitas $77 \%$ dan spesifisitas $82 \%$ yang dapat menunjukkan adanya perbaikan klinis pada penurunan skor 2 poin. ${ }^{17-19}$ Kebutuhan obat antikolinesterase (Piridostigmin atau Neostigmin) juga berhubungan dengan beratnya kelemahan otot pada pasien MG. ${ }^{1-2,4}$

\section{TUJUAN}

Mengetahui perbandingan kondisi klinis pasien MG antara sebelum dan setelah dilakukan timektomi di RSUP Dr. Hasan Sadikin, Bandung.

\section{METODE}

Penelitian ini merupakan suatu penelitian kohort retrospektif dengan mengumpulkan data serial sejak sebelum pasien menjalani tindakan timektomi sampai dengan 6 bulan setelah timektomi di RSUP Dr. Hasan Sadikin, Bandung, pada bulan Januari 2014

Tabel 1. Klasifikasi MGFA

\begin{tabular}{|c|c|c|}
\hline Derajat I & & $\begin{array}{l}\text { Kelemahan otot mata dan/atau kelopak mata } \\
\text { Kekuatan semua otot lain normal }\end{array}$ \\
\hline Derajat IIa & - & $\begin{array}{l}\text { Kelemahan otot ringan selain mata, predominan otot ekstremitas dan/atau batang tubuh } \\
\text { Dapat disertai kelemahan otot mata dengan berbagai tingkat keparahan }\end{array}$ \\
\hline $\mathrm{IIb}$ & $\begin{array}{l}\circ \\
\circ\end{array}$ & $\begin{array}{l}\text { Kelemahan otot ringan selain mata, predominan otot bulbar } \\
\text { Dapat disertai kelemahan otot mata dengan berbagai tingkat keparahan }\end{array}$ \\
\hline Derajat IIIa & - & $\begin{array}{l}\text { Kelemahan otot sedang selain mata, predominan otot ekstremitas dan/atau batang tubuh } \\
\text { Dapat disertai kelemahan otot mata dengan berbagai tingkat keparahan }\end{array}$ \\
\hline IIIb & $\begin{array}{l}0 \\
\circ\end{array}$ & $\begin{array}{l}\text { Kelemahan otot sedang selain mata, predominan otot bulbar } \\
\text { Dapat disertai kelemahan otot mata dengan berbagai tingkat keparahan }\end{array}$ \\
\hline Derajat IVa & $\bullet$ & $\begin{array}{l}\text { Kelemahan otot berat selain mata, predominan otot ekstremitas dan/atau batang tubuh } \\
\text { Dapat disertai kelemahan otot mata dengan berbagai tingkat keparahan }\end{array}$ \\
\hline $\mathrm{IVb}$ & $\begin{array}{l}0 \\
\circ\end{array}$ & $\begin{array}{l}\text { Kelemahan otot berat selain mata, predominan otot bulbar } \\
\text { Dapat disertai kelemahan otot mata dengan berbagai tingkat keparahan }\end{array}$ \\
\hline Derajat V & \multicolumn{2}{|c|}{ Terintubasi, dengan maupun tanpa ventilasi mekanik } \\
\hline
\end{tabular}


Tabel 2. Myasthenia Gravis-Activities of Daily Living (MG-ADL)

\begin{tabular}{|c|c|c|c|c|}
\hline Variabel & $\mathbf{0}$ & 1 & 2 & 3 \\
\hline 1. Bicara & Normal & $\begin{array}{l}\text { Cadel atau sengau } \\
\text { hilang timbul }\end{array}$ & $\begin{array}{l}\text { Cadel atau sengau terus- } \\
\text { menerus namun dapat } \\
\text { dimengerti }\end{array}$ & $\begin{array}{l}\text { Bicara sulit } \\
\text { dimengerti }\end{array}$ \\
\hline 2. Mengunyah & Normal & $\begin{array}{l}\text { Kelelahan dengan } \\
\text { makanan padat }\end{array}$ & $\begin{array}{l}\text { Kelelahan dengan makanan } \\
\text { lunak }\end{array}$ & $\begin{array}{l}\text { Selang makan } \\
\text { (gastric tube) }\end{array}$ \\
\hline 3. Menelan & Normal & Jarang tersedak & $\begin{array}{l}\text { Sering tersedak, perlu } \\
\text { perubahan jenis makanan }\end{array}$ & $\begin{array}{l}\text { Selang makan } \\
\text { (gastric tube) }\end{array}$ \\
\hline 4. Bernapas & Normal & Sesak dengan aktivitas & Sesak pada waktu istirahat & $\begin{array}{l}\text { Tergantung } \\
\text { ventilator }\end{array}$ \\
\hline $\begin{array}{l}\text { 5. Gangguan } \\
\text { kemampuan } \\
\text { menyikat gigi/ } \\
\text { menyisir rambut }\end{array}$ & Tidak ada & $\begin{array}{l}\text { Usaha lebih besar, } \\
\text { namun tidak perlu } \\
\text { waktu istrahat }\end{array}$ & Perlu waktu istirahat & $\begin{array}{l}\text { Tidak dapat } \\
\text { melakukan salah } \\
\text { satu fungsi ini }\end{array}$ \\
\hline $\begin{array}{l}\text { 6. Gangguan } \\
\text { kemampuan } \\
\text { bangun dari } \\
\text { tempat duduk }\end{array}$ & Tidak ada & $\begin{array}{l}\text { Ringan, kadang } \\
\text { menggunakan bantuan } \\
\text { lengan }\end{array}$ & $\begin{array}{l}\text { Sedang, selalu menggunakan } \\
\text { bantuan lengan }\end{array}$ & $\begin{array}{l}\text { Berat, perlu } \\
\text { bantuan orang lain }\end{array}$ \\
\hline $\begin{array}{l}\text { 7. Pandangan ganda } \\
\text { (diplopia) }\end{array}$ & Tidak ada & $\begin{array}{l}\text { Terjadi, namun tidak } \\
\text { setiap hari }\end{array}$ & $\begin{array}{l}\text { Setiap hari, namun tidak terus- } \\
\text { menerus }\end{array}$ & Terus-menerus \\
\hline $\begin{array}{l}\text { 8. Kelopak mata } \\
\text { turun (ptosis) }\end{array}$ & Tidak ada & $\begin{array}{l}\text { Terjadi, namun tidak } \\
\text { setiap hari }\end{array}$ & $\begin{array}{l}\text { Setiap hari, namun tidak terus- } \\
\text { menerus }\end{array}$ & Terus-menerus \\
\hline
\end{tabular}

hingga Desember 2016. Subjek penelitian ini adalah pasien MG berusia 17-65 tahun yang telah menjalani timektomi, dalam pengobatan teratur Piridostigmin atau dinyatakan remisi dari penyakit $\mathrm{MG}$, terdapat hasil histopatologi untuk kelenjar timus, dan bersedia ikut serta dalam penelitian.

Kriteria eksklusi apabila terdapat komorbid yang berat dan tidak berhubungan dengan MG, seperti penyakit jantung yang berat, gangguan ginjal atau hati, diabetes melitus, stroke, polineuropati berat, maupun pasien yag memiliki penyakit autoimun lain, seperti systemic lupus erythematosus, Graves, reumatoid artritis).

Dilakukan wawancara dan pengisian kuesioner pada bulan Mei-Juni 2017 dengan mengevaluasi perbandingan dosis Piridostigmin per hari, performa fungsional menggunakan MG-ADL, dan derajat klinis berdasarkan klasifikasi MGFA antara sebelum dan setelah dilakukan timektomi.

Total skor MG-ADL berkisar antara 0-24, dengan skor 0 adalah normal dan skor 24 menunjukkan adanya performa fungsional dan klinis yang sangat berat. Penurunan skor MG-ADL lebih dari sama dengan 2 poin berarti perbaikan klinis. Subjek dinyatakan remisi jika tidak mengonsumsi Piridostigmin selama $\geq 1$ tahun, tanpa gejala atau maksimal kelemahan kelopak mata. Analisis statistik menggunakan SPSS 21.0 for Windows.

\section{HASIL}

Didapatkan 27 subjek dengan rerata usia $36,6 \pm 14,5$ dan proporsi perempuan (74\%) lebih banyak daripada laki-laki dengan perbandingan 2,8:1 (Tabel 3). Tingkat keparahan subjek cukup berat (rerata klasifikasi MGFA IVa) dengan durasi menderita $\mathrm{MG} \leq 24$ bulan (59,3\%).

Pada penelitian ini, didapatkan 16 orang yang sudah dilakukan timektomi lebih dari 1 tahun sebelum penelitian dilakukan, dengan jumlah subjek yang mengalami remisi sebanyak 3 orang $(16,7 \%)$. Sebelas orang sisanya belum mencapai 1 tahun sehingga tidak dapat dinilai remisinya.

Tabel 4 menunjukkan penurunan dosis Piridostigmin per hari setelah timektomi, dari rerata dosis satu bulan sebelum timektomi 240 (180-540) mg menjadi $180(0-480) \mathrm{mg}$ setelah 6 bulan secara bermakna $(p=0,0452)$. Skor MG-ADL juga semakin menurun, dari median dalam satu bulan sebelum 
Tabel 3. Karakteristik Subjek Penelitian $(n=27)$

\begin{tabular}{|c|c|c|}
\hline Variabel & n (\%) & $\mathbf{p}$ \\
\hline Usia [rerata (tahun)] & $36,4 \pm 14,5$ & \\
\hline \multicolumn{3}{|l|}{ Usia awitan MG (tahun) } \\
\hline $\begin{array}{l}\text { - Perempuan } \\
\text { - Laki-laki }\end{array}$ & $\begin{array}{l}27,7 \pm 11,1 \\
40,8 \pm 17,1\end{array}$ & \\
\hline $\begin{array}{l}\text { Dosis Piridostigmin sebelum } \\
\text { timektomi (mg) }\end{array}$ & $\begin{array}{l}240(180- \\
540)\end{array}$ & \\
\hline Skor MG-ADL sebelum & $10(4-21)$ & \\
\hline
\end{tabular}

timektomi

Klasifikasi MGFA sebelum IVa (IIa-V)

timektomi

Durasi MG

- $\leq 24$ bulan

- $>24$ bulan

$16(59,3 \%)$

$11(40,7 \%)$

0,336

Usia saat timektomi

- $<40$ tahun

$\bullet \geq 40$ tahun

$17(63 \%)$

$10(37 \%)$

0,178

MG: miastenia gravis; MG-ADL: Myasthenia Gravis-Activities of Daily Living; MGFA: Myasthenia Gravis Foun dation of America.

tindakan timektomi sebesar 10 (4-21) menjadi 3 (018) pada 6 bulan setelah tindakan timektomi $(p=0,001)$.

Klasifikasi MGFA subjek sebelum timektomi seluruhnya (100\%) merupakan MG generalisata dengan rerata derajat IVa (rentang IIa-V) yaitu MG generalisata derajat berat dengan dominan kelemahan otot ekstremitas dan batang tubuh (Tabel 4). Pada 6 bulan setelah timektomi menurun menjadi derajat IIb (rentang normal-V), yaitu pasien MG generalisata derajat ringan dengan dominan kelemahan otot bulbar $(\mathrm{p}<0,001)$.

Jumlah MG okular menjadi sebanyak 22,2\% dan pasien tanpa gejala sebanyak 7,4\%, sedangkan pasien MG generalisata menurun menjadi $70,4 \%$ (Tabel 5). Dari 27 orang subjek penelitian, didapatkan 21 orang $(77,8 \%)$ mengalami perbaikan derajat MGFA 6 bulan setelah timektomi, sedangkan 6 orang $(22,2 \%)$ lainnya menetap atau mengalami perburukan (Tabel 5).
Tabel 5. Klasifikasi MGFA Subjek (n=27)

\begin{tabular}{lcc}
\hline \multirow{2}{*}{ Klasifikasi MGFA } & \multicolumn{2}{c}{$\mathbf{n ~ ( \% )}$} \\
\cline { 2 - 3 } & $\begin{array}{c}\text { Sebelum } \\
\text { Timektomi }\end{array}$ & $\begin{array}{c}\text { Setelah } \\
\text { Timektomi }\end{array}$ \\
\hline Normal/tanpa gejala & 0 & $2(7,4)$ \\
Derajat I & 0 & $6(22,2)$ \\
Derajat II a & $2(7,4)$ & $2(7,4)$ \\
Derajat II b & $1(3,7)$ & $7(25,9)$ \\
Derajat III a & $4(14,8)$ & $5(18,5)$ \\
Derajat III b & $4(14,8)$ & $2(7,4)$ \\
Derajat IV a & $5(18,5)$ & $1(3,57)$ \\
Derajat IV b & $8(29,6)$ & 0 \\
Derajat V & $3(11,1)$ & $2(7,4)$ \\
\hline MGFA: Myasthenia Gravis Foundatiom of America.
\end{tabular}

Tabel 6 menunjukkan bahwa durasi subjek menderita MG sebelum timektomi dan usia saat dilakukan timektomi tidak memengaruhi perbaikan derajat MGFA pada 6 bulan setelah timektomi $(p>0,05)$.

\section{PEMBAHASAN}

Usia subjek penelitian ini serupa dengan penelitian di Iran dengan median 38 (16-60) tahun, sedangkan di Brazil 41,8 (17-72) tahun..$^{20-21}$ Demikian pula proporsi perempuan lebih banyak daripada laki-laki dengan perbandingan 2,8:1, seperti halnya Poomthong dkk. di Thailand (2,6:1), Barnett dkk di Kanada (2,1:1), maupun Lorenzoni dkk di Brazil $(4,9: 1) .^{20,22-23}$

Usia awitan MG pada perempuan sebagian besar muncul pada usia 20-30 tahun, sedangkan lakilaki umumnya muncul pada usia yang lebih tua, yaitu lebih dari 40 tahun. ${ }^{24}$ Sesuai dengan penelitian ini, rerata usia awitan MG subjek perempuan lebih muda daripada laki-laki $(27,7 \pm 11,1$ tahun versus $40,8 \pm 17,1$ tahun).

Dalam penelitian ini, rerata dosis Piridostigmin per hari menurun secara bermakna dalam 6 bulan setelah timektomi. Penelitian oleh Tellez-Zentero, dkk. di Mexico mendapatkan rerata dosis Piridostigmin per

Tabel 4. Dosis Piridostigmin, Skor MG-ADL, dan Klasifikasi MGFA (n=27)

\begin{tabular}{lccc}
\hline \multicolumn{1}{c}{ Variabel } & Sebelum Timektomi & Setelah Timektomi & \multirow{2}{*}{$\mathbf{p}^{*}$} \\
\cline { 2 - 4 } & Median $\left(\mathbf{x}_{\text {min }}-\mathbf{x}_{\text {maks }}\right)$ & Median $\left(\mathbf{x}_{\text {min }}-\mathbf{x}_{\text {maks }}\right)$ & 0,0452 \\
Dosis Piridostigmin $(\mathrm{mg})$ & $240(180-540)$ & $180(0-480)$ & 0,001 \\
MG-ADL & $10(4-21)$ & $3(0-18)$ & $<0,001$ \\
Klasifikasi MGFA & IVa (IIa-V) & IIb (normal -V) & \\
\hline
\end{tabular}

*Uji Wilcoxon Matched Pairs; MG-ADL: Myasthenia Gravis Actifities of Daily Living; MGFA: Myasthenia Gravis Foundation of America. 
Tabel 6. Hubungan antara Durasi MG dan Usia Saat Timektomi dengan Perubahan Derajat Klinis $(\mathrm{n}=27)$

\begin{tabular}{|c|c|c|c|c|}
\hline \multirow[b]{2}{*}{ Variabel } & \multirow[b]{2}{*}{$\begin{array}{c}\text { Total } \\
\text { Subjek }\end{array}$} & \multicolumn{2}{|c|}{ Klasifikasi MGFA } & \multirow[b]{2}{*}{$\mathbf{p}^{*}$} \\
\hline & & $\begin{array}{c}\text { Perbaikan } \\
\text { n }(\%)\end{array}$ & $\begin{array}{c}\text { Menetap/ } \\
\text { Perburukan } \\
\text { n (\%) }\end{array}$ & \\
\hline \multicolumn{5}{|l|}{ Durasi MG } \\
\hline - $\leq 24$ bulan & 16 & $14(87,5)$ & $2(12,5)$ & \multirow{2}{*}{0,187} \\
\hline - $>24$ bulan & 11 & $7(63,6)$ & $4(36,4)$ & \\
\hline \multicolumn{5}{|l|}{ Usia saat Timektomi } \\
\hline - $<40$ tahun & 17 & $15(88,2)$ & $2(11,8)$ & \multirow{2}{*}{0,153} \\
\hline - $\geq 40$ tahun & 10 & $6(60)$ & $4(40)$ & \\
\hline
\end{tabular}

*Uji Fisher's Exact Test; MG: miastenia gravis; MGFA: Myasthenia Gravis Foundation of America.

hari sebelum timektomi 319,1 (rentang 90-720) mg yang diobservasi setiap 3 bulan sampai dengan 3 tahun dengan rerata dosis setelah timektomi menurun menjadi sebesar 263,5 (rentang 0-720) mg. ${ }^{25}$ Beberapa penelitian di Thailand menyatakan bahwa perbaikan klinis MG dapat terlihat sejak 2 bulan setelah timektomi, bahkan perbaikan gambaran elektrofisiologis dapat terlihat mulai satu minggu setelah timektomi. ${ }^{23-24}$

Secara teoretis, sel B dan sel Thelper abnormal yang sudah bersirkulasi dalam darah akan tetap bertahan untuk jangka waktu yang cukup lama, bahkan mencapai berbulan-bulan sampai bertahuntahun, meskipun sumber autoimunisasi sudah disingkirkan dengan tindakan timektomi. Oleh sebab itu, perbaikan klinis dan penurunan dosis obat dapat berbeda pada setiap individu. Apabila diikuti dalam jangka waktu yang lebih lama, jumlah pasien yang mengalami perbaikan akan semakin banyak. ${ }^{26}$

Pada penelitian ini terdapat $16,7 \%$ subjek yang mengalami remisi, sesuai dengan studi Muhammed dkk yang menyatakan angka pencapaian remisi berkisar $13-46 \%$ pada pasien MG yang diikuti selama 3 bulan sampai 10 tahun setelah timektomi. ${ }^{15}$

Rerata skor MG-ADL penelitian ini menurun sangat bermakna antara sebelum dan 6 bulan setelah timektomi. Oleh karena itu, dapat dilihat bahwa seiring dengan berjalannya waktu, performa fungsional pasien pasca-timektomi semakin membaik. Penelitian di Texas, Amerika Serikat menyatakan bahwa MG-ADL merupakan alat ukur yang masih relevan meskipun dibandingkan dengan alat ukur yang lebih baru seperti Myasthenia Gravis-Quality of Life $(M G-Q o L){ }^{17}$

Dalam satu bulan sebelum timektomi, klasifikasi MGFA subjek penelitian ini seluruhnya merupakan MG generalisata, tidak didapatkan pasien dengan MG okular maupun tanpa gejala klinis. Hal ini sama dengan Poomthong dkk, bahwa subjek penelitian sebelum timektomi didominasi oleh pasien $\mathrm{MG}$ generalisata $(84,3 \%$, dan hanya $15,7 \%$ dengan $\mathrm{MG}$ okular.

Sebanyak 77,8\% subjek penelitian ini mengalami perbaikan derajat MGFA 6 bulan pascatimektomi, sesuai dengan Muhammed dkk tahun 2016 bahwa perbaikan klinis dapat terlihat pada 5494\% pasien MG yang diikuti selama 3 bulan sampai 10 tahun pasca-timektomi. ${ }^{15}$

Serupa dengan hasil penelitian ini, Huang dkk di Taiwan dan Takanami dkk menyatakan bahwa pasien dengan durasi $\mathrm{MG} \leq 24$ bulan sebelum timektomi lebih mungkin mengalami perbaikan daripada $>24$ bulan. ${ }^{27-28}$ Semakin lama durasi MG, maka fungsi sel T akan semakin abnormal seiring dengan progresifitas penyakit MG. Aghajanzadeh dkk pada tahun 2007 menyatakan bahwa terdapat banyak faktor yang memengaruhi keberhasilan tindakan timektomi, salah satunya adalah usia saat pasien dilakukan timektomi. Pasien dengan usia saat timektomi $<40$ tahun memiliki angka perbaikan klinis yang lebih tinggi. ${ }^{29}$

Penelitian ini bersifat retrospektif dengan menggunakan kuesioner mengenai dosis obat dan kemampuan aktivitas hidup harian, sehingga bias memori subjek menjadi kendala yang paling utama. 
Selain itu, jumlah sampel yang sedikit dan hanya dilakukan di satu institusi menyebabkan penelitian ini tidak dapat melihat hubungan maupun pengaruh tindakan timektomi terhadap luaran klinis pasien MG dan tidak dapat diaplikasikan pada populasi umum pasien MG di Indonesia yang menjalani timektomi. Oleh karena itu, perlu dilakukan penelitian menggunakan studi kohort prospektif untuk menghindari bias memori dan penelitian dengan jumlah sampel yang lebih besar dan multisenter untuk dapat menilai hubungan atau pengaruh jenis kelainan kelenjar timus terhadap luaran pasien MG pasca-timektomi.

\section{KESIMPULAN}

Terdapat penurunan yang bermakna antara dosis Piridostigmin per hari, skor MG-ADL, dan klasifikasi MGFA antara 1 bulan sebelum dan 6 bulan setelah timektomi. Didapatkan penurunan yang bermakna antara skor MG-ADL sebelum dengan 3 bulan setelah timektomi. Sebanyak $16,7 \%$ pasien yang telah menjalani timektomi selama lebih dari satu tahun mengalami remisi.

Ditemukan pula subjek dengan durasi MG $\leq 24$ bulan pada saat dilakukan timektomi memiliki persentase perbaikan klinis lebih besar dibandingkan subjek dengan durasi MG lebih dari 24 bulan. Subjek dengan usia kurang dari 40 tahun pada saat dilakukan timektomi memiliki persentase perbaikan klinis lebih besar dibandingkan subjek berusia lebih dari atau sama dengan 40 tahun.

\section{DAFTAR PUSTAKA}

1. Romi F. Thymoma in myasthenia gravis: from diagnosis to treatment. Autoimmune Dis. 2011;2011:474512.

2. Sanders DB, Wolfe GI, Benatar M, Evoli A, Gilhus $\mathrm{NE}$, Illa I, dkk. International consensus guidance for management of myasthenia gravis: executive summary. Neurology. 2016;87(4):419-25.

3. Gentile R, Capone L, Schoenhuber R. Thymusrelated myasthenia gravis. Multimodal therapy and follow up. Dalam: Lavini C, Moran CA, Morandi U, Schoenhuber R, editor. Thymus gland pathology: clinical, diagnostic, and therapeutic features. Italy: Springer; 2008. h. 247-54.

4. Khadilkar SV, Sahni AO, Patil SG. Myasthenia gravis. J Assoc Physicians of India. 2004;52:897-904.

5. Kumar V, Abbas AK, Aster JC. Hematopoietic and lymphoid systems. Robbins basic pathology. Edisi ke-9. Philadelphia: Elsevier Saunders; 2013. h. 456-7.
6. Lucchi M, Ricciardi R, Melfi F, Duranti L, Basolo F, Palmiero G, dkk. Association of thymoma and myasthenia gravis: oncological and neurological results of the surgical treatment. European $\mathrm{J}$ Cardiothorac Surg. 2009;35(5):812-6.

7. Mao ZF, Mo XA, Qin C, Lai YR, Hackett ML. Incidence of thymoma in myasthenia gravis: a systematic review. J Clin Neurol. 2012;8(3):161-9.

8. Murthy JM. Thymectomy in myasthenia gravis. Neurol India. 2009;57(4):363-5.

9. Raica M, Ribatti D. Head and neck; thymus: thymoma: an overview. Atlas of Genetics and Cytogenetics in Oncology and Haematology. 2012.

10. Raica M, Cimpean AM, Ribatti D. Myasthenia gravis and the thymus gland. A historical review. Clin Exp Med. 2008;8(2):61-4.

11. Mourao AM, Araujo CM, Barbosa LS, Gomez RS, Burns TM, Lemos SM, dkk. Brazilian cross-cultural translation and adaptation of the questionnaire of life quality specific for myasthenia gravis-15 items. Arq Neuropsiquiatr. 2013;71(12):955-8.

12. habitAAM, RosliNA, Solehan HM, Pilus Z. Validation study of the Malay version of the Myasthenia Gravis Quality of Life (MGQOL) 15 and Myasthenia Gravis Activites of Daily Living (MGADL) questionnaires. Neurol Asia. 2016;21(1):33-9.

13. Dalakas MC. Treating myasthenia on consensus guide: helpful and challenging but still unfinished business. Neurology. 2016;87(4):350-1.

14. Gilhus NE, Verschuuren JJ. Myasthenia gravis: subgroup classification and therapeutic strategies. Lancet Neurol. 2015;14(10):1023-36.

15. Muhammed J, Chen CY, Wan Hitam WH, Ghazali MZ. Thymectomy for myasthenia gravis: a 10 -year review of cases at the hospital Universiti Sains Malaysia. Malays J Med Sci. 2016;23(4):71-8.

16. Jayam-Trouth A, Dabi A, Solieman N, Kurukumbi M, Kalyanam J. Myasthenia gravis: a review. Autoimmune Dis. 2012;2012:874680.

17. Muppidi S, Wolfe GI, Conaway M, Burns TM, Mg C Mg-Qol15 Study G. MG-ADL: still a relevant outcome measure. Muscle Nerve. 2011;44(5):727-31.

18. Tapia CB. Development and validation of a new measure of impairment in myasthenia gravis: the myasthenia gravis impairment index. Toronto: University of Toronto; 2015.

19. Thabit M, Adlan A, Rosli NA, Solehan HM, Pilus Z, Lotfie MM, Sahathevan R, dkk. Validation study of the Malay version of the Myasthenia Gravis Quality of Life (MGQOL)15 and Myasthenia Gravis Activities of Daily Living (MGADL) questionnaires. Neurology Asia. 2016;21(1):33-9.

20. Lorenzoni PJ, Augusto LP, Kay CS, Scola RH, 
Werneck LC. Myasthenia gravis and thymus: longterm follow-up screening of thymectomized and non-thymectomized patients. Arq Neuropsiquiatr. 2013;71(7):462-4.

21. Mozzaffar M, Fard A, Kharazm P, Kermani H, Aminseresht M, Yavari P. Thymectomy after plasmapharesis in myasthenia gravis: results of long term follow up. Tanaffos. 2007;6(1):23-8.

22. Barnett C, Katzberg HD, Keshavjee S, Bril V. Thymectomy for non-thymomatous myasthenia gravis: a propensity score matched study. Orphanet J Rare Dis. 2014;9(1):214.

23. Poomthong $\mathrm{P}$, Arayawichanont A. Response of thymectomy in myasthenia gravis patients: a one year retrospective study at Sappasithiprasong hospital, Thailand. Noth-Eastern Thai J Neurosci. 2010;7(2):71-8.

24. Witoonpanich R. Evaluation of electrophysiological response to thymectomy in patients with myasthenia gravis. J Med Assoc Thai. 2004;87(11):1301-3.
25. Tellez-Zenteno JF, Cardenas G, Estanol B, GarciaRamos G, Weder-Cisneros N. Associated conditions in myasthenia gravis: response to thymectomy. Eur J Neurol. 2004;11(11):767-73.

26. Kumar N, Verma AK, Mishra A, Agrawal G, Agrawal A, Misra UK, dkk. Factors predicting surgical outcome of thymectomy in myasthenia gravis: a 16-year experience. Ann Indian Acad Neurol. 2011;14(4):267-71.

27. Huang CS, Hsu HS, Huang BS, Lee HC, Kao KP, Hsu WH, dkk. Factors influencing the outcome of transsternal thymectomy for myasthenia gravis. Acta Neurol Scand. 2005;112(2):108-14.

28. Takanami I, Abiko T, Koizumi S. Therapeutic outcomes in thymectomied patients with myasthenia gravis. Ann Thorac Cardiovasc Surg. 2009;15(6):373-7.

29. Aghajanzadeh M, Khoshrang H, Mohammadzadeh A, Roudbari SA, Ghayeghran AR. Thymectomy for myasthenia gravis: prognostic factors in 70 patients. Asian Cardiovasc Thorac Ann. 2007;15(5):371-5. 